\title{
SIT-TIGHTISM IN AFRICA: AN EXPOSITORY ANALYSIS
}

\author{
SEVERUS IFEANYI ODOZIOBODO, PhD \\ Department of Political Science \\ Enugu State University of Science and Technology, \\ Enugu, Nigeria \\ siodoziobodo@gmail.com
}

\begin{abstract}
Democracy has gained currency among Africans as the best form of government but the extent to which the leaders bastardize its application is mind boggling and needs to be discussed for democratic consciousness among various stakeholders. It is against this backdrop that this paper undertakes to explore one of the anti-democratic trends in Africa's politics namely, sit-tightism, a phenomenon as well as a practice whereby an elected president uses suppression of the opposition and manipulation of the constitution to truncate his abdication of power after his constitutionally mandated term of office has elapsed and thereby stays put in office. This practice is against one of the cardinal tenets of democracy which is, term limits, always spelt out in a country's constitution. Using the historical analytical method as well as the realist/power theory approach as a framework for analysis, the paper explores the strategies employed in accomplishing this undemocratic phenomenon and discovers that the practice is a burden on democracy in Africa and also an affront on democratic consolidation as well as a nemesis to socio-economic and political development of affected nations in particular and the African continent in general. The paper recommends democratic consciousness among the citizenry as well as regional and global denouncement and sanctions against any nation involved as a deterrent.
\end{abstract}

Key words: Africa, constitution, democracy, sit-tightism and term limit.

\section{INTRODUCTION}

That Africans have embraced democracy as the best form of government is no longer in contention, what is however in contention is the degree to which they apply democratic principles in their practice of democracy. Since the early $80 \mathrm{~s}$ when the wave of democratization swept through Africa, most African countries had embraced democracy and are trying vigorously to climb the ropes but it has not been an easy task. Getting it right with democracy has been problematic asthe continent falters with some of its principles. "There is no doubt that in African politics today, there is no choice but democracy. Yet, beneath the progressive veneer of democratization lies a lot of ambivalence and contradictions," (Obi 2008). One instance of the bastardization of democracy in Africa is thesit-tight syndromewhich has become the rule rather than the exception among African presidents since independence. At the end of their tenures which are normally spelt out in their country's constitutions, most African presidents had employed all kinds of measures ranging from constitutional coups, intimidation of the opposition, refusal to conduct election to outright refusal to quit office irrespective of the consequences. The situation is such that by 2019, three African heads of state had been in power for more than three decades each: Teodoro Obiang Nguema Mbasogo in Equatorial Guinea, Paul Biya in Cameroon and Yoweri Museveni in Uganda. More than a dozen other African heads of state have been in power for at least ten years. In August 2017, Angolan President Jose Eduardo Santos stepped down 
after thirty-eight years in office and in November of that year, Zimbabwean president, Robert Mugabe was forced out of office througha military coup after thirty-seven years as President,(Claire Felter, 2019).

This is despite the fact that in the mid-1990s, the global wave of democratization inspired a momentum for competitive party politics in Africa which offered a viable alternative to the seemingly troubled autocratic regimes, (Namakula, 2016). Thus, Africa's agenda transformed to include promotion of democratic principles and institutions, popular participation and good governance, (AU, 2000). One of the ways of promoting democratic principles is by limiting the tenure of a country's political leadership. Hence,democracy makes provision for the conduct of periodic election for power succession asa cardinal principle. Namakula (2016) insists that limiting the tenures of the top leadership of a nation is arguably one of the most fundamentals of democratic principles and she notes that due to the challenge of streamlining the transition of power, the measure quickly gained prominence among African countries. In this regard, Dulani (2015) notes that forty-nine (49) of the sixty-four (64) constitutions adopted or amended between 1990 and 2010 in Africa incorporated term limits, which represent three (3) quarters of the enactments.

As a matter of fact,imposing term limits to restrain autocracy is an ancient idea that formed part of the origins of democracy. "Experience", they say, "is the best teacher" and Klaas (2015), made us understand that the cities of Rome and Athens were compelled to impose term limits on their rulers due to events that happened during the reign of Peisistratos - the tyrant of Athens between 546 BC- 510 BC, in which many Athenians fled or were forced into exile, (Tangian, 2014). From then onwards, it has become a practice synonymous with democracy that nations include term limits in their constitution.

In the same vein, most African countries complied with term limits in their constitutions in order to become democracy compliant. A study conducted by Afrobarometer between 20112013 among thirty-four (34) African countries, revealed strong support for presidential term limits among three (3) quarters of the citizens of the countries surveyed, including those where term limits had been scrapped, such as Togo and Uganda, (Dulani, 2016). Most country's constitution limits the tenures of their presidents to two terms of four or five years each,after which the president must vacate office and would not be eligible to contest for the presidency again. The implication of this development is that Africa progressed in terms of its practice of democracy. However, though African democracy has shown some improvements, with elections becoming more frequent and more regular in some parts of the continent, few African states are still characterized by corruption and autocracy. In such states, the incumbent cows the opposition and exploits the power of the state to skew the electoral contest in his favour. In some other climes especially in Eastern and Central Africa, constitutional coups appear to be the new tools incumbents employ to sidestep term limits. This, they do, by amending the provisions of a national constitution to achieve tenure elongation, (Abdulateef and Modestus, 2017).

In any case, attempts to elongate the tenures of presidents in Africa have not gone unchallenged and the after effect had been conflicts upon conflicts. The African continent is known for conflict and has the highest number of conflicts in the world today.Oche (2006) laments that although conflicts are taken to be an inherent aspect of human relations, whether at the group, national or international levels, the prevalence of conflicts on the African continent in contemporary times has assumed the dimension of a scourge; indeed the issue has become such a serious problem that it is arguably the greatest impediment to any meaningful form of development on the African continent today. Unfortunately, one of the triggers of conflict in Africa has been tenure elongation situations that have resulted in the loss of millions of lives, widespread displacement and a wide array of human rights abuses. Today, Africa accounts for about 70 percent of United Nations peacekeeping operations and 
Africa continues to suffer from violent conflicts. In Somalia, in Sudan's Darfur region, in the Eastern Democratic Republic of Congo, the toll has been devastating. Insecurity, displacement, and destruction are the order of the day (Oche, 2006).

Consequently, this paper explores one of the features of Africa's politics namely, sit-tightism, a phenomenon as well as a practice whereby an elected president uses suppression of the opposition and manipulation of the constitution to prolong his stay in power beyond his constitutionally mandated terms of office. This practice is an observed trend among African presidents andit is undemocratic. The paper draws a table showingsit-tight leaders in Africa; the strategies employed and its implications on socio-economic and political development of the affected countries as well as on the consolidation of democracy in Africa. Recommendations on how to remedy the situation and strengthen democracy in Africa are also proffered.

\section{CONCEPTUALIZINGSIT-TIGHTISM}

The phrase, "sit-tightism" like many others in the social and management sciences has been devilled by lack of universally accepted definition. Consequently, divergent views have been portrayed by scholars on its meaning. The Oxford Advanced Learners' Dictionary conceptualizes it as the act of staying in the same situation without changing one's mind or taking any action. It further views it as the act of staying where one is rather than moving away or changing position.

However, Uhara's (2013) definition is apt to our discussion in this paper. He defines sittightism as the willful reluctance on the part of a political leader to relinquish power. In the context of this paper, sit-tightism means a practice whereby an elected president refuses covertly or overtly to relinquish power at the expiration of his tenure of office. Sit-tightism presupposes that there is term limits for a president in the constitution of the affected country but the president uses some deliberate machinations to prolong or elongate his tenure of office as against constitutional provisions and popular choices.

\section{THORETICAL FRAMEWORK}

The theoretical framework adopted for the analysis of this work is political realism, otherwise known as power theory.Although a theory of international relations, the theory can be used for other issues/events. In the understanding of realists, man is naturally egoistic and perpetually pre-occupied with the desire to dominate others and the only way to achieve this is by the acquisition of power. Political realism sees the world as a wicked place where man must not think of cooperation with others for there is nothing like that. Man therefore, must, at all times do everything possible to outwit the others and to do this; man must have power; for it is only through the agency of power that man can get whatever he wants in society. Realists believe in the efficacy of power and for them, power acquired must be consolidated.Foremost realists includeNicolle Machiavelli, Thomas Hobbes,Jean Jacque Rousseau and Clausewitz as well as Hans Morgenthau (1904-80).

For this paper, we shall specifically employ the services of a contemporary realist, Hans Morgenthau (1904-80), a German scholar who propagated the twin theories of power and greed and who bringing the wisdom of Machiavelli and Clausewitz with him contended that international politics, like all politics, is a struggle for power (Roskin, 1994:3). If this is the case, man must, as a matter of necessity, try to acquire power, and power acquired must be sustained and consolidated and if possible should not be dropped for whatever reason since man needs power at all times. It is in recognition of this that Robert Greene (1998) authored his much celebrated work, The 48 Laws of Power, where he discussed the modus operandi and modus vivendi of acquiring and consolidating power. For instance, he admonishes humanity in his law number twenty four to play the perfect courtier for "it is a fact of human nature that 
the structure of a court society forms itself around power.... Great courtiers throughout history have mastered the science of manipulating people. They make the king feel more kingly; they make everyone else fear their power." Greene (1998) also admonishes that in order to consolidate power, man must be ruthless, hence in Law Fifteen, he admonishes that enemies should be crushed totallyso as to avoid a situation whereby the enemy defeated halfway, recovers and seeks revenge.

Asobie (2007) also contends that power (read force or violence) is needed and used primarily for consolidating and expanding power. For him, the end of power is power and the means to power is power itself. Every other thing or purpose is secondary. State power is thus all about acquiring the monopoly of the use of the instruments of violence within a particular community (Asobie, 2007). Conceiving politics in this manner implies the valourization of power, an acceptance of the view that might is right and this makes the realist perspective a war prone conception of politics (Asobie, 2007).

The realist theory is apt for the analysis of sit-tightism because it is about the acquisition and consolidation of state power even beyond tenure limits. Since presidents in Africa are in love with power and do everything possible to cling unto power, they are apostles of realism. Many African heads of states are oblivious of the fact that power is transient and ephemeral. They want to cling unto power for life forgetting that much as they want power, other people also want it.Abiodun, et al (2018) concludes that it is this power-seeking and greed perspective of African leaders who by all means want to maintain a sit-tight syndrome and ensure tenure elongation in politics that breeds political instability and violent conflicts in Africa. This is evident in some countries in Africa; Zimbabwe, Gambia, Sudan, Congo, and others.

\section{OVERVIEW OF SIT-TIGHT PRESIDENTS IN AFRICA}

Experiences from several African countries over the years have shown that African heads of state have a tendency to perpetuate themselves in office. It is like a natural trait with Africans and it runs through their blood to the extent that once they get into power; they would not want to leave power until they are forced out or they die in office. A Guardian Editorial (2005)corroborates this when it notes that "with a few notable exceptions, there is and has been reluctance among Africa's leaders to relinquish power. Whether they ascended through a military coup or civilian election, no sooner they get there than they begin plotting and scheming to stay in power indefinitely."

Currently, many African heads of state are sit-tighting; a lot would want to and some had tried to, but could not succeed. Those who stepped down from office within the time they were supposed to, did that willy-nilly. Those who had tried and failed and those who would want to but cannot, are only prevented from accomplishing their unbridled folly due to the political consciousness of the citizenry of their various countries. For instance, Zambia's Frederick Chiluba in 2002, Malawi's Bakili Muluzi in 2004, Nigeria's Olusegun Obasanjo in 2007 and Zambia's Yayah Jammeh in 2017 were only prevented from sit-tighting at a great cost to their various countries after they had tried vigorously to extend their rules. Blaise Compaoré of Burkina Faso was only prevented from hanging onto power in 2014 owing to mass protests which forced him to flee. Robert Mugabe in Zimbabwe never intended to quit power until he was forced out of office through a military coup in 2017 after 37 years in office.

Nonetheless, much as many had tried and failed, some are already accomplished sit-tighters; from Teodoro Obiang Nguema Mbasogo of Equitorial Guinea to Eduardo Dos Santo of Angola and Paul Biya of Cameroon. These are men still on the seat against the tenets of democracy which they claim to practice and uphold. Indeed, the list of Africa's sit-tight presidents is long. However, there are some African countries likeLibya, Egypt, Tunisia and 
Burkina Faso whose presidents, sit-tighted but who were forced to step down against their will.

No doubt, sit-tightism in Africa did not start today as Kunuj (2016) notes that it has a long and troubling history in Africa. It is characterized by a willful reluctance on the part of political leaders to relinquish power. It is facilitated by dictatorship and oiled by brutal repression of dissent and fundamental freedoms, (Inegbedion, 2010). Such was the case in Libya under Muhammar Gaddaffi from 1968 to 2011. It was also the case under Mobutu Seseseko of the DRC from 1965 to 1997; Mathieu Kerekou of Benin Republic from 1972 to 2006; Felix Houphouet Boigny of Cote d'ivoire from 1960 to 1993, Gnassingbe Eyadema of Togo from 1967 to 2005 and Robert Mugabe of Zimbabwe from 1980 to 2017. In all the cases mentioned above, power has been retained against the will of the citizenry, ( Fombad \& Inegbedion, 2010) and it is antithetical to the principle and practice of democracy. This phenomenon which can be described as the foremost weakness of leaders of Africa and the Third World has shown them to be vain, greedy, immature and inconsiderate.

The situation is such that while 34 African countries have two-term limit provisions in their constitutions, only 20 percent of these term limits have been complied with, (Ried, 2014).

Below is a table showing some African presidents and the number of years they were or have been in power, indicating sit-tightism.

\begin{tabular}{|c|c|c|c|c|}
\hline $\mathbf{S} / \mathbf{N}$ & Name of Sit-tight President & Country & $\begin{array}{l}\text { No.of years } \\
\text { in power }\end{array}$ & $\begin{array}{ll}\text { Duration of } \\
\text { Stay } & \text { in } \\
\text { power } & \end{array}$ \\
\hline 1. & TeodoroNgumaMbasogo & Equatorial Guinea & 40 years & Since 1979 \\
\hline 2. & Paul Biya & Cameroon & 37 years & Since 1982 \\
\hline 4. & YoweriMuseveni & Uganda & 37 years & Since 1982 \\
\hline 5. & Mswati 11 & Swaziland & 33 years & Since 1986 \\
\hline 6. & BlaiseCampore & Burkina Faso & 32 years & Since 1987 \\
\hline 7. & Omar Bashir & Sudan & 30 years & Since 1989 \\
\hline 8. & Idriss Deby & Chad & 29 years & Since 1990 \\
\hline 9. & Isaias Afwerki & Eritrea & 28 years & Since 1991 \\
\hline 10. & Issias Afewerki & Eritrea & 26 years & Since 1993 \\
\hline 11. & Meles Zenawi & Ethiopia & 24 years & Since 1995 \\
\hline 12. & Pakalitha Mosisili & Lesotho & 21 years & Since 1998 \\
\hline 13. & Denis Sassou Nguesso & Republicof the Congo & 22 years & Since 1997 \\
\hline 14. & $\begin{array}{l}\text { TeodoroObiangNguema } \\
\text { Mbasogo }\end{array}$ & Equatorial Guinea & 22 years & Since 1997 \\
\hline 15. & Ismail Omar Guelleh & Djibouti & 20 years & Since 1999 \\
\hline 16. & Mohammed VI & Morocco & 20 years & Since 1999 \\
\hline 17. & $\underline{\text { Ismaïl Omar Guelleh, }}$ & Djibouti & 20 years & Since 1999 \\
\hline 18. & Laurent Gbagbo & Ivory Coast & 19 years & Since 2000 \\
\hline 19. & Paul Kaigama & Rwanda & 19 years & Since 2000 \\
\hline 20. & Abdoulaye Wade & Senegal & 19 years & Since 2000 \\
\hline 21. & SalvaKiir Mayardit & South Sudan & 14 years & Since 2005 \\
\hline 22. & Faure Gnassingbé & Togo & 14 years & Since 2005 \\
\hline 23 & Pierre Nkurunziza & Burundi & 14 years & Since 2005 \\
\hline 24 & Ali Bongo Ondimba & Gabon & 10 years & Since 2009 \\
\hline 25 & Mohamed Ould Abdel Aziz & Mauritania & 10 years & Since 2009 \\
\hline 26 & Moummar Ghaddafi & Libya & 44 years & 1967- 2011 \\
\hline 27 & Jose Don Santos & Angola & 38 years & $1979-2017$ \\
\hline
\end{tabular}


DOI : https://dx.doi.org/10.26808/rs.aj.i8v1.04

American Journal of Sustainable Cities and Society

Issue 8, Vol. 1 January- December 2019

Available online on http://www.rspublication.com/ajscs/ajsas.html

ISSN $2319-7277$

\begin{tabular}{|l|l|l|l|l|}
\hline \hline 28 & Robert Mugabe & Zimbabwe & 37 years & $1980-2017$ \\
\hline 29 & Hosni Mubarak & Egypt & 30 years & $1981-2011$ \\
\hline 30 & Omar al-Bashir & Sudan & 30 years & $1989-2019$ \\
\hline 31 & Ben Ali & Tunisia & 23 years & $1988-2011$ \\
\hline 32 & Yahya Jammeh & Gambia & 23 years & $1994-2017$ \\
\hline 33 & Abdelaziz Bouteflika & Algeria & 20 years & $1999-2019$ \\
\hline 34 & Joseph Kabila & $\begin{array}{l}\text { Democratic Rep the } \\
\text { Congo }\end{array}$ & 18 years & $2001-2019$ \\
\hline
\end{tabular}

Table showing some African Presidents who were or had been in power for more than 10 years indicating sit-tightism.

\section{MECHANISMS OF ACHIEVING SIT-TIGHTISM IN AFRICA}

In order to prolong their stay in office beyond their term limits, sit-tight leaders not only in Africa but in other countries of the world use a lot of strategies including the following:

\section{1. . Constitutionalcoup}

The major way through which desperate sit-tight leaders in Africa achieve their goal is by organizing constitutional coup which entailstinkering with their country's constitution by extending or abolishing term or age limits in the constitution."Simply put, a constitutional coup is an attempt to review or amend the provisions of a national constitution by an incumbent leader with the ulterior motive of capitalizing on such amendments to achieve tenure elongation", (Adibe,2016). They employ the services of their cronies in the parliament to pass a law to change either the term or the age limit depending on which enables them stay as long as they want; some even for life as the case may be. Some presidents organize a referendum in which citizens vote for or against the constitutional amendment.

The irony of the whole scenario is that in most cases; the people vote in favour of the constitutional amendment even when they are aware of the intention of the plotters. The reason is simple; the incumbent president enjoying the power of incumbency cajoles, manipulates and coaxes the citizenry to buy into their proposal. Any dissenting voice becomes a dissident and an enemy who must be crushed with state power. Imagine 98 per cent of Rwandans voting in favour of a constitutional change to permit Paul Kagame, 58, to run for a third term of seven years at the end of his tenure in 2017. The country's amended constitution which reduced a term from seven years to five years was plotted to come into effect when Kagame's third term tenure of seven years came to an end, enabling him to run for another two terms of 5-years each under the amended constitution. This makes it possible for him to rule until 2034 - or longer if he is able to organize another constitutional coup after that.

Another example is the case of Uganda where a constitutional amendment was engineered just to change the age limit in order to accommodate the incumbent president. According to the Punch Editorial (2008) "the Ugandan example has shown how African countries continue to make a mockery of themselves in the comity of nations by claiming to practice democracy when indeed their actions portray the worst form of despotism. At 73, Museveni would have been more than 75 years old - the statutorily allowable age to vie for the presidency in that country - by the next presidential election in 2021. But in a seemingly pre-emptive strike, he made sure that the age barrier was removed".

Whatever the situation, the fact remains that constitutional coup has become a feature of Africa's politics. Adrienne LeBas (2016) notes that between 2000 and 2015, fifteen African leaders attempted to stay in power by removing term limit provisions from constitutions. The majority of these attempts were successful, but she notes that the tide may now be turning against "third-termism." Ken Okpalo (2015) also notes that since the early 1990s, 24 
presidents in Sub-Saharan Africa initiated discussions in attempts to stay in office for more than two terms when confronted with term limits. In 15 countries presidents started the process of actually amending the constitution. In 12 of these cases (Burkina Faso, Burundi, Cameroon, Chad, Gabon, Guinea, Namibia, Niger, Rwanda, Senegal, Togo, and Uganda) the presidents succeeded. In three (Malawi, Nigeria, and Zambia) they failed. At the same time, leaders in Benin, Cape Verde, Ghana, Kenya, Mali, Mozambique, Sao Tome and Principe, Tanzania, and recently Namibia have adhered to constitutional term limits without a protracted challenge.

Extending or abolishing term limits is not unique to the African continent. Russia's President, Vladimir Putin won a fourth term in March 2018 after changes to the constitution and some nimble political footwork. Just recently, the Chinese parliament voted to abolish term limits allowing for the possibility of President Xi Jinping becoming president for life. Given that Russia and China play an influential role on the African continent, these events don't bode well for the future of presidents sticking to term limits on the continent, notes The Conversation (2018).

However, in spite of whatever measure they use in achieving their aim, successful constitutional coups indicates lack of political consciousness on the part of the citizenry of the affected countries. After all, attempts at constitutional coup had been resisted in some countries like the case of Frederick Chiluba in 2001 and more recently Edgar Lungu in Zambia, Olusegun Obasanjo of Nigeria (2005), Mamadou Tandja of Niger(2009-2010) and Blaise Compaore of Burkino Faso (2014).

\section{Harassing and intimidating the opposition}

Another strategy through which African presidents achieve their sit-tightism is by harassing and intimidating the opposition. In order to achieve their aim, they do everything possible to silence the opposition who are meant to oppose them and who also try to make the masses aware of what they intend to do. Sit-tight leaders keep themselves in office by the suppression of their people through arbitrary arrests, detentions, torture, and all types of human rights violations.

The Punch Editorial (2018) gives example of the case of Uganda where, "the crude method of intimidating and hounding the opposition was employed. Not only were some legislators opposed to the constitutional amendment on age cap suspended for alleged "unruly behaviour" in parliament, security men suspected to be soldiers from an elite military unit entered the chamber and violently ejected 25 "enemy" parliamentarians, to ensure an unhindered passage of the amendment. This was despite the fact that the ruling party had a comfortable majority in the parliament".

\section{Claim to messianic mission in the country}

In order to justify as well as achieve their aim of overstaying in power, sit-tight presidents give citizens of their country the impression that they are god-sent and as such they do not need to leave power since that will spell doom for their countries. They claim that they are the only people who can make a difference in the governance of their country. "Usually, the tyrants paint a messianic picture of themselves, claiming that only they can hold the country together. But, as demonstrated by the ouster of Hosni Mubarak in Egypt after 29 years; Muammar Gadaffi in Libya after 40 years; and Jose Eduardo dos Santos who ruled Angola for 38 years, nobody can claim to have the magic wand to rule over a people in perpetuity. So, the people of Uganda, or any other country, as the case may be, should be able to claim their country from impostors and opportunists who parade themselves as leaders", The Punch Editorial (2018). 
Bribery and corruption

In many cases, sit-tight leaders in Africa resort to bribing members of the parliament because they cannot achieve their aim without the parliament amending the constitution so, they resort to bribing members of the parliament in order to pass the amendment in a way to suit their purpose. They also bribe other powerful stakeholders in order to allow them elongate their tenures. They use money, award of contracts and allocation of oil wells as the case may be to induce strong members of the opposition to allow them carry on with their desired aims of elongating their terms of office.

\section{SIT-TIGHTISM AND AFRICA'S DEVELOPMENT}

The high expectations of the people that democracy would reverse decades of poverty, corruption and underdevelopment have hardly been met by the new democrats; this can be credited to the undemocratic practice of sit-tight leaders that are at the helm of affairs of virtually every Africa country. These presidents come to office and instead of having the welfare of the people and development of the country in mind rather prioritize enriching themselves and family at the expense of the development of the nation, (Obi, 2000).

Sit-tight leaders do not think of the development of their nations, rather they think of how to hold onto power and consolidate it, as well as plunder the nation. According to Mohan and Power (2009) "leaders who go into power and decide to sit-tight do so with the intention to enrich themselves with the resources and wealth of the country, leaving the economic and general development of the country to her fate." Right from the day they are sworn in as presidents of their countries, most of them begin plotting how to continue in office even after the end of their constitutional terms. With this mindset, they hardly do much to improve the fortunes of their countries developmentally. At the end of their tenures, they begin the main fight of continuing in power with the obvious conflicts attached. In the midst of all these, the development of their countries suffers serious setbacks.Imagine that even till date, virtually all African countries, after decades of independence are still being described as underdeveloped, while few are described as developing despite the huge natural endowments of both material and human resources. The major cause of this is the breed of leaders (sit-tight leaders) and leadership style found in Africa. The Sun Editorial(2017), notes that governance may not be an exact science but experience all over the world has shown that four years is enough for leaders to demonstrate their skills and talents. A second four years is the maximum period after which it becomes apparent that new ideas would be required and new blood infused if the country is to continue to develop. The Editorial concludes that Africa will continue its backward slide as long as leaders refuse to quit at the appropriate time. Sittightism has become like a curse on the continent that all hands must be on deck to reverse it if the continent as a whole or at least some of Africa countries must get a glimpse of what it feels like to be among the developed countries of the world (Sun Editorial, 2017).

Sight-tightism brings about despotic leadership and, abuse of human rights is always the case. The effect is that citizens of the affected country leave the country in their droves, heading to other countries, thereby losing serious manpower. Odoziobodo and Nnaji (2017) cite the instance of what happened in the Gambian during the sit-tight era of Yahaya Jammeh. The issue was so serious that several opposition figures, including Barrow, made stopping migration a central theme in their campaigns. No doubt, migration of people out of the country affected the economic development of Gambia adversely. In the same vein, any country where there is a sit-tight leader, people are repressed and they leave the country with their knowledge and expertise, thereby making the country lack manpower which is tantamount to stalled development.

Sit-tightism is anti- developmental. Not only does the affected country suffer the ill effects, neighboring countries are also not spared. It goes with conflicts and displacement ofpeople 
and in the course of that, citizens flee the country and swell the population of neighboring countries. Forthis reason, Durotoye (2016), insists that sit-tightism in Africa"portends serious threat to the region's economic outlook. The direct impact of the refugee inflow creates considerable financial burden on the impoverished host nations. The second impact results from changes in domestic and international investment sentiment. No investor goes to invest where there is conflict. Could the AU have done better? The organization's hands were tied because of the reluctance on the part of heads of state to condemn the dangerous trend apparently because many of them are also guilty of the same political manipulation. Besides, the practice of decision-making by consensus within the AU makes it more difficult".

\section{DANGER OF HAVING SIT-TIGHT PRESIDENTS}

Not only that it is undemocratic, having sit-tight presidents is in no way desirable for any country. It is said that power corrupts but absolute power corrupts absolutely. Presidents, who stay too long in power, acquire excess power and excess wealth that nobody dare challenge them. They become lords unto themselves and rule with impunity.

Sit-tighting is obviously not without a fight. It is never gotten on a platter of gold. It goes with repression and sometimes protests at a great cost to the affected country, costs in terms of human loss and others. Apart from the above reason, "some of them grow too old and senile, becoming a liability to their countries. Not only do they lack fresh ideas, even some of those ones who started well later lost their lustre. A good example is Museveni. Once hailed as progressive, he is now enveloped in corruption, nepotism and intolerance of opposing views. In his recent appointments, he made his wife, Janet Kataaha, a cabinet minister, while promoting his son, Muhoozi Kainerugab - whom many believe is being groomed to take over from him - to the position of a major general in the army,(Abiodum et al., 2016). A man like Robert Mugabe, the former president of Zimbabwe, who stayed in power as president from 1980 -2017 "had turned his country, once a veritable food basket, into a miserable basket case. The economy is now in a complete shambles, where millions of Zimbabwean dollars cannot buy a loaf of bread", notes the Punch Editorial (2018). This is as a result of his refusal to quit office when his tenure was over and the resultant effect of lack of ideas as occasioned by senility.He would have saved his country all these problems had he quit when he was due. Again, according to Okorie (2016),, "Tenure elongation projects are expensive exercises, often achieved using scarce state resources. This is a subtle political hijack of the democratic process, which ironically is then justified using democratic arguments of respecting the choice of a people in who leads them. It is quite frankly the import of autocracy through democratic back channels. It comes at very steep costs to democracy- the erosion of political competition; the enthronement of political infallibility; the modern colonization of the democratic space; the distortion of the developmental impetus, as political objectivity gives way to political survival; the triumph of minority hubris over majority reticence; the fusion of the state and the individual; and the beginning of the piecemeal death of democracy".

\section{WAY OUT OF SIT-TIGHTISM}

There is an urgent need to safeguard democracy in Africa as Africans have fought many wars to reach this stage.I advocate for a war on sit-tightism in Africa in order to save democracy. Africans cannot afford to allow those they elected into power to lord it over them and impose themselves on them whether they like it or not. This can be done by ways of protests and demonstrations and all other activities that border on civil disobedience. Obi (2008) suggests that there will have to be a struggle for a third independence for African people. The first was against colonialism, the second against internal dictatorship, and the third will be directed at transforming the democracy from above to one from below. For except power returns to the people in a concrete sense, African cannot enjoy the full dividends of democracy. More 
importantly, the people have to control the states in Africa, and transform them into agencies for the collective will and development within the framework of a new equitable peoplecentred social contract. Yet, Africans cannot afford to ignore the realities of multiparty democracy as the only game in town, nor can the world continue to shut its eyes and ears to the contradictions in and the very severe pains that the policies it promotes in the continent directly or indirectly inflict on the people.

For democracy to thrive; citizens must resist the temptation of being complacent. Everybody in all countries of Africa must be alert to resist elected presidents whenever they start trying to change the goal-post in the middle of the game. Whenever a sitting president starts talking of changing the constitution in Africa, we must be alerted that he is up to tenure elongation. There is need for democratic consciousness in Africa and among Africans. Promoting term limits has become a central element of US diplomacy on the continent. Former US President, Barack Obama spoke of term limits as a core feature of democratization, declaring that "Africa's democratic progress is at risk when leaders refuse to step aside when their terms end," LeBas (2016).

Ehindero, (2016) notes that to foster sustainable democracy, a nation must focus its efforts on building a system that empowers people not only through the right to vote, but also through entrenched norms, institutions and values that supports those rights and makes them meaningful. Each country on the continent needs to bolster its strengths and banish its fears. In vibrant western democracies with entrenched citizenship, democracy is sustained when individuals, groups, and guilds subsume their competing and countervailing egos and selfpride under the rubric of higher national interests. A way out is the need for constant innovation by taking another look at the political architecture of nations and re-align it in such a way that it liberates, and harmonizes the competing and countervailing energies and geniuses of their diverse people. In a multi-ethnic nation, what holds true for genuine federalism also holds for genuine democracy as no power bloc nor a cultural unit be in a position to lord it over the others or possess veto power on the democratic destiny of the nation. (Ehindero, 2016).

The way and manner the revolution rubbished sit tight governments in Egypt and Libya is no doubt a big lesson to all countries of Africa. Such revolutions are due and may likely take place in other countries of Africa where the heads of states refuse to vacate office at the end of their tenures even when they are not doing well.

Inasmuch as a country is supposed to be sovereign, it does not mean that even when an impunity is taking place as it is wont to happen in many African countries especially when a president completes his tenure and refuses to leave office, that other countries and World bodies should turn a blind eyes to the sufferings of the people and leave one "man" to lord it over the majority. The world should take a cuefrom ECOWAS' intervention in the Gambian political logjam in 2017 when the former president of Gambia, Yahya Jammeh refused to vacate office at the expiration of his tenure. If ECOWAS had not intervened, a bloody civil war would have taken place in the Gambia, leading to the death and displacement of many Gambians and the resultant swelling of refugee camps in the neighboring countries. The success of that singular intervention is a proof that involving external bodies such as ECOWAS, the African Union, AU and the United Nations, UN in such instances, can go a long way to stopping the undemocratic syndrome of sit-tightism in Africa.

\section{RECOMMENDATIONS}

1. Recommendation is hereby made for a fourth independence for African people as Obi (2008) suggested for a third independence. According to him, "The first was against colonialism, the second against internal dictatorship, and the third will be directed at transforming the democracy from above to one from below. For except power returns to 
the people in a concrete sense, African cannot enjoy the full dividends of democracy. More importantly, the people have to control the states in Africa, and transform them into agencies for the collective will and development within the framework of a new equitable people-centred social contract. Yet, Africans cannot afford to ignore the realities of multiparty democracy as the only game in town, nor

2. The fourth independence for African people will be a struggle to end sit-tightism. Africans cannot be said to be practicing democracy when one of the cardinal principles of democracy, namely, term limit, is constantly trampled upon.

3. Africans must realize that there is no option to democracy and they must fight hard to preserve their hard earned victory against dictatorship, for the worst democracy is better than the best military dictatorship. "Africans cannot afford to ignore the realities of multiparty democracy as the only game in town," (Obi, 2008).

4. The African Union and other regional bodies like ECOWAS, etc., should institutionalize a policy of zero tolerance to sit- tightism in Africa just the way the body and others institutionalized zero tolerance to military coups. This gave them the latitude to intervene in the political crises in Guinea Bissau, Sao Tome and Principe, and Zimbabwe when democracy was threatened in those countries.

5. Africans must resist sit-tight presidents through protests; demonstrations and all nonviolent means available to them as such had helped to scare sit-tight leaders in some African countries. One major way out of it is for citizens to resist the temptation of being complacent and put fear of the unknown behind and stand for their right at all cost;

6. The international community must assist Africans in the fight against sit-tightism as the resultant conflicts occasioned by it are too good to be ignored. "The world cannot continue to shut its eyes and ears to the contradictions in and the very severe pains that the policies it promotes in the continent directly or indirectly inflict on the people", (Obi, 2008).

7. World and regional bodies must help to stem the tide of sit-tightism in Africa taking a cue from the success of ECOWAS' intervention in the Gambian political logjam in which Yahya Jammeh, who wanted to sit-tight was forced to flee the Gambia in 2017.

8. The conscious building and nurturing of stronger democratic institutions with the devolution of more powers to the other arms of government should be encouraged in Africa to stem the tide of sit-tightism.

9. Democratic consciousness and political vigilantism are recommended for all citizens of Africa. The essence is to preventAfrican presidents from ever nursing the ambition, not to talk of sit-tighting in office..

\section{CONCLUSION}

It is a truism that there is no alternative to democratic government in Africa. If this is the case as it is, then democracy needs to be entrenched in Africa; it needs to be consolidated. Democratic consolidation in the views of Linz and Stepan is a process by which all political actors come to regard democracy as 'the only game in town'. In other words, democracy is consolidated when citizens and leaders alike conclude that no alternative form of regime has any greater subjective validity or stronger objective claim to their allegiance, Linz and Stepan (1996).Incidentally, one of the impediments to democratic consolidation in Africa is the sittight syndrome. The earlier it is defeated, the better for democracy.

Unfortunately, the tragedy of the African continent is that the African Union, AU is implicated in the sit-tight problem of the continent. Since most of the presidents of member States are also plotting to sit-tight, who then fight the battle to end the scourge in Africa?The recommendations of this paper above if followed religiously will assist Africa in the 
decimation of the sit-tight syndrome and thereby lead to the consolidation of democracy in Africa.

\section{REFERENCES}

1. Abiodun, T.F., Nwannennaya, C., Ochei, B.O., Ayo-Adeyekun, I. (2018). "Sit-Tight Syndrome and Tenure Elongation in African Politics: Implications for Regional Development and Security". IOSR Journal of Humanities and Social Science (IOSRJHSS) Volume 23, Issue 4.

2. Abdullateef, S. and Modestus, U. (2017, July 26). Sit-Tight Syndrome and Tenure Elongation in African Politics: Implications for Regional Development and Security. Daily Trust Newspaper.

3. Adibe, J. (2016). Africa: From Military Coups to Constitutional Coups. ICGPS The Sahel Consortium. Available at http://www.sahelconsortium.org/blogs/2016/1/13/africafrom-military-coups-to-constitutional-coups-2.

4. African Union (AU) (2000) Constitution of the African Union. Available at:

5. http:/ www.un.org/en/africa/osaa/pdf/au/constitutive_act_african_union_2000.pdf

6. Asobie, E. (2007). Theories of Power, Greed and Political Studies. South Africa: ThinkThank Publishers.

7. Dulani, B. (2016). African Publics Strongly Support Term Limits, Resist Leaders' Efforts to Extend their Tenure. Afrobarometer Dispatch No. 30. Available at:http://afrobarometer.org/sites/default/files/publications/Dispatches/ab_r6_ dispatchno30.pdf

8. Durotoye, A. (2016). "Resurgent Backsliding and Democracy in Africa". International Journal of African and Asian Studies, Vol. 18

9. Ehindero, T. J., (2016). "Guerrilla democracy: an emerging trend of democracy in Africa". International Journal of Advanced Academic Research in Social \& Management Sciences (2) 9.

10. Eze K., (2016).The Efficacy Of Presidential Term Limits In Africa Discussion Paper, Mandela Institute For Development Studies Minds Annual African Youth Dialogue 3-4 August 2016 Dar Es Salaam, Tanzania 2016.

11. Felter, C. (2017).Africa's Leaders for Life. Available at: https://www.cfr.org/politics-andgovernment/heads-state-and-government

12. Fombad C. \& Inegbedion N. A., (2010). 'Presidential Term Limits And Their Impact on Constitutionalism in Africa' in Charles Fombad and Christina Murray (ed)., Fostering Constitutionalism in Africa, (Pretoria University Law Press, 2010).

13. Greene, R (2000). The 48 Laws of Power. New York: Penguin Books.

14. Guardian Editorial (Dec. 6, 2005). Africa's Sit -Tight Leaders. Culled from: https://dawodu.com/guardian4.htm

15. Issaka, K.S.,(21 June 2016). The AU and the Challenge of Unconstitutional Changes of Government in Africa, ISS Paper 197, August 2009, p. 4. Last accessed from https://www.issafrica.org/acpst/papers/the-au-and-the-challenge-of-unconstitutionalchanges-of-government-in-africa

16. Klaas, B. (1 June, 2015), Two elections and you're out? Good Governance. Available at: http://gga.org/stories/editions/aif-32-shaky-foundations/two-elections-and-you2019re-out

17. Kunuj W. (Feb.26, 2016). 'Sit-tightism' and Constitutionalism in Africa. Available at: https://lexlataconsult.com/2016/02/27/ constitutionalism-in-africa/

18. LeBas, A. (2016). "Term Limits and Beyond: Africa's Democratic Hurdles." Current Histories. http://www.currenthistory.com/CurrentHistory_LeBas.pdf 
19. Linz, J. \& Stepan, A. (1996) Problems of Democratic Transition and Consolidation: Southern Europe, South America, and Post-Communist Europe. Baltimore, Md: Johns Hopkins University Press.

20. Mohan, G and Power, M. (2009). "Africa, China and the 'new' economic geography of development". Singapore Journal of Tropical Geography, Vol.30 (1).

21. Namakula, C.S (2016). "The Efficacy Of Presidential Term Limits In Africa." Discussion Paper, Mandela Institute for Development Studies. Dar Es Salaam, Tanzania.

22. Obi, C.I. (2008).No Choice but Democracy: Prising the People out of Politics in Africa.Claude Ake Memorial Papers No. 2. Sweden: Department of Peace and Conflict Research, Uppsala University \& Nordic Africa Institute.

23. Obi C. I. (2000), “Last Card: Can Nigeria survive another transition?"African Journal of Political Science vol. 5, no. 2.

24. Oche, S. (2005) "Cooperating with Civilians and the Security Forces in Efforts to Combat the Proliferation of Small Arms and Light Weapons" in A. Ayissi and I. Sall (eds)

25. Odoziobodo, S.I \& Nnaji, E. (2017). "ECOWAS and the Fight against Sit-tightism in West Africa: A Case Study of the Gambian 2016-2017." International Journal of Multidisciplinary and Current Research, Vol.5.

26. Okorie, I. (January 27, 2016). Tenure Elongation and Developmental Deficits in Africa. Available at: http://www.africasyndicateblog.com/blog/2016/1/27/tenure-elongation-anddevelopmental-deficits-in-africa-the-curse-of-larger-than-life-leadership-hubris

27. Okpalo, K. (2015) Term Limits and Democratic Consolidation in Sub-Saharan Africa: Lessons from Burundi. Constitutionnet. Available at:

http://constitutionnet.org/news/term-limits-and-democratic-consolidation-sub-saharanafrica-lessons-burundi

28. Roskin, A.Z. (2004). Political Theories: A Compendium of Knowledge. London: University Press.

29. Riedl, R. B. (2014). Authoritarian Origins of Democratic Party Systems in Africa”, Cambridge: Cambridge University Press

30. Sun Editorial ( $8^{\text {th }}$ January, 2017). Africa's sit-tight Rulers. Available at: (http://sunnewsonline.com/africas-sit-tight-rulers/)

31. Tangian, A., (2014). Mathematical Theory of Democracy. London: Springer.

32. The Punch Editorial (Jan. 4, 2018). Museveni rises to tenure elongation bait

33. The Punch Editorial (January, $4^{\text {th }}, 2019$ ) Museveni rises to tenure elongation bait. Avaialable at: https://punchng.com/museveni-rises-to-tenure-elongation-bait/

34. The Conversation $\left(2019,14^{\text {th }}\right.$ May).Presidential term limits: slippery slope back to authoritarianism in Africa. (May 17, 2018).https://theconversation.com/presidential-termlimits-slippery-slope-back-to-authoritarianism-in-africa-96796 . Accessed 14th May, 2019.

35. The Conversation. (February 8, 2017,) Africa faces a new threatto democracy: The constitutional coup. Available at:https://theconversation.com/africa-faces-a-new-threatto-democracy-the-constitutional-coup-72011,

36. The Sun Editorial o( 8th January 2017). "Africa's sit-tight rulers.” Available at:

37. (http://sunnewsonline.com/africas-sit-tight-rulers/).

38. Uhara, E.E. (2013) Africa's Democracy: Dynastic Rule or Sit-Tightism Rule? Tnv

39. The Nigerian Voice. Available at: https://punchng.com/museveni-rises-to-tenureelongation-bait/ 